\title{
A Test of the Technology Acceptance Model for Understanding the ICT Adoption Behavior of Rural Young Entrepreneurs
}

\author{
Zeinab Zaremohzzabieh ${ }^{1}$, Bahaman abu Samah ${ }^{1}$, Mahazan Muhammad ${ }^{1}$, Siti Zobidah Omar ${ }^{1}$, Jusang Bolong ${ }^{1}$, \\ Md Salleh Hassan ${ }^{1} \&$ Hayrol Azril Mohamed Shaffril ${ }^{1}$ \\ ${ }^{1}$ Institut Pengajian Sains Sosial, UPM, Malaysia \\ Correspondence: Zeinab Zaremohzzabieh, Institut Pengajian Sains Sosial, UPM, Malaysia. E-mail: \\ zeinabzaremohzzabieh@yahoo.com
}

Received: November 28, 2014

Accepted: December 19, 2014

Online Published: January 20, 2015

doi:10.5539/ijbm.v10n2p158

URL: http://dx.doi.org/10.5539/ijbm.v10n2p158

\begin{abstract}
Information and communication technologies (ICTs) open up new opportunities for rural young entrepreneurs to enhance their businesses. However, the challenges of adopting and using ICTs obstruct these businesses from growing into drivers for rural-economic development and job creation. The purpose of this paper is to seek to validate the technology acceptance model (TAM), which measures the volitional aspect of the ICT adoption behavior of young entrepreneurs in a rural community. In order to test the model, data are collected using self-administered questionnaires from 400 rural youth entrepreneurs. The structural equation modeling technique (SEM) was applied to assess the model. The results confirmed that TAM is robust enough to gauge the dimensions of young entrepreneurs' adoption of ICT by way of the model accounting for 55 percent of the variance in intention to use ICT. They also indicated that attitude toward entrepreneurship partially mediated the relationship between ICT's usefulness and entrepreneurial intention. This paper will serve to illuminate this model and reveal new knowledge perspectives. Policy makers could encourage rural youth entrepreneurs to use ICT in their businesses, which will in turn inspire other entrepreneurs to look up to these adopters and follow them, thus increasing the use of ICT in rural communities.
\end{abstract}

Keywords: Rural community, young entrepreneurs, ICT adoption behavior, technology acceptance model

\section{Introduction}

Young entrepreneurs are playing an increasingly important role in local economies and a high proportion of microenterprises in most developing regions are established by rural youth (Ahmad et al., 2011; McMullen, Bagby, \& Palich, 2008; Norhaiyati, Nik, \& Md, 2011). Over the last two decades, rural youth frequently have had primary responsibility for making important contributions to rural economies and agricultural production, although the number of rural youth has decreased as a result of some negative experiences of natural demographic growth in rural communities, and of rural-urban drift. Previous studies and surveys have shown that the choice of entrepreneurship as a future career is considered as an important source of livelihood for rural youth (e.g., Lichtenstein, Lyons, \& Kutzhanova, 2004; Markley, Macke, \& Luther, 2005; Pages, Freedman, \& Von Bargen, 2003). According to Omolo (2011), entrepreneurship development is a key pillar of a self-employment strategy for helping youth to be more productive members of their communities and achieve economic independence.

Furthermore, with the incentives of a credit profile, foundations and government programs, and loans related to entrepreneurship, the use of information and communication technologies (ICTs) can increase the attractiveness of entrepreneurship for rural youth and can sensitize them regarding their use of entrepreneurship (Sabri et al., 2008). Arunachalam (2004) asserted that rapid ICT development also has led to a growth of interest in using ICTs for rural community development. Undoubtedly, developments in ICT have removed some of the restraints to such development, as it is a considerable generator of income, spreads tasks, increases productivity, speeds up communication, creates jobs, and much more (Ghazy et al., 2008; Rahman et al., 2005).

On the other hand, even though the adoption of ICTs is only one way to control or access markets in unexpected ways, a study by Ramsey et al. (2003) provides statistically important results on small and medium enterprises: that only $33 \%$ of the self-employed had a website, but that most did not have an e-entrepreneurship business case. Other review papers present the low rate of adoption of ICT across businesses in rural regions (Wolcott, Mehruz, 
\& Sajda, 2008). Likewise, research on success in rural small businesses through ICT shows a low rate of ICT adoption among remote rural businesses compared to urban businesses (Anderson, Tyler, \& McCallion, 2005). Thus, more research is needed to seek more reliable and accurate explanations for the ICT adoption behavior of rural youth.

In order to assess ICT adoption behavior, the technology acceptance model (TAM; David, 1989) has been widely used by several researchers in many technology adoption studies (e.g., Alshare \& Alkhateeb, 2008; Anandarajan et al., 2010; Liu, 2010; Yuen \& Ma, 2008). The purpose of this paper is to use TAM to reflect other factors-i.e, perceived usefulness (PU), perceived ease of use (PEOU), and attitude (AT) to technology acceptance-to answer the question of how and why young entrepreneurs adopt and use ICT in rural communities, and also to trace ICT use and adoption to classify any connected changes in outdated business behavior and the intention of these entrepreneurs regarding marketplaces and commercial innovations.

\subsection{Entrepreneurship in Rural Areas}

From a review of two decades of entrepreneurship literature, most definitions of rural entrepreneurship have borrowed from concepts such as "risk taking," "successfully undertaking a business venture," "innovation," and "drive, capabilities, and organizational skills," which are similar to definitions of urban entrepreneurship (Wortman, 1990, p. 330). Only a few studies have started to distinguish entrepreneurship in rural studies from entrepreneurship in urban studies. For example, Henderson, Low, and Weiler (2007) differentiated rural and urban entrepreneurship by different place attributes and different local factors.

More rural communities are turning to entrepreneurship development as a sustainable source of occupations and local income that can provide support for local businesses, and it is progressively being taken seriously as a way to recover local economies (Barrios \& Barrios, 2008; Dabson, 2007). Frequently, local economies in rural regions are controlled by agriculture and by one industry, exposing them to greater levels of risk taking than their counterparts in urban areas (Dabson et al., 2003). However, in terms of firms, self-employment across all rural sectors grew and even outpaced levels of self-employment growth within urban sectors by the 1980s. The generation of income in rural areas from entrepreneurship is about 31 percent lower on average than in urban areas (Henderson, 2002).

According to Henderson (2002), rural entrepreneurs have a tendency to engage in three industries: services, retail trade, and construction. These constitute about $69.4 \%$ of rural self-employment; in addition, $10 \%$ of rural self-employment is engaged in natural resource industries and non-farm agriculture. The study was conducted in Canada and presented the differences in rates of rural-urban self-employment activity. It showed that even though the dissimilarities between rural and urban self-employment decline after the agriculture data are omitted from the sample, rural workers were still characterized as a large percentage of all Canadian self-employed workers (Plessis, 2004). By increasing the proportion of self-employed workers in rural areas, particularly in non-farm activities, one thing that can be done to support rural entrepreneurship is to include youth in enterprise activities, helping them to attain economic independence and diminishing their dependence on state welfare. This indirectly fosters an environment for economic growth and development in national and regional aspects (Mutezo, 2005).

\subsection{Entrepreneurship and Rural Youth}

With the economic importance of entrepreneurship, there are many good reasons why it is important to adhere to entrepreneurship for rural youth. Many researchers consider that this could bring local and marginalized youth back into the economic mainstream and give them a sense of belonging, an opportunity to address some of the delinquency and socio-psychological difficulties that arise from unemployment, and helping them develop new experiences and skills that can then be related to further challenges in life (Chigunta, 2002; Curtain, 2000).

ILO (2008) emphasized that though youth entrepreneurship could not solve the unemployment problems among young people, it did play an important role. Entrepreneurship could bring stability in global market economic demand and lead to finding opportunities in self-employment (Chigunta, 2001; Schoof, 2006). In addition, it can be a source of economic dynamism and new occupations, and it can also recover the livelihoods of rural youth and their economic independence in developing regions. According to Llisterri et al. (2006), entrepreneurship is progressively taken as a significant path to innovation and a helpful alternative for income generation among young people.

The benefits from entrepreneurship in rural areas include the fact that it can reflect the predominant trends in these communities and that new economic prospects can be a significant avenue of opportunity for rural youth. This is especially important given that it is increasingly accepted that youth entrepreneurs can present a new 
perspective to the market, especially in alternatives to the organization of work and the transfer of technology (White \& Kenyon, 2000). Within the agenda of possible efforts to boost employment for rural youth, ICT is a new way of incorporating youth into the labour market.

\subsection{Supporting Rural Youth Entrepreneurs through ICTs}

The adoption of ICTs in a rural community is one of the strategies for development that offer possible opportunities for entrepreneurial activity to overcome some of the obstacles that are a consequence of distance (Hollifield \& Donnermeyer, 2003). ICT is significantly more than physical software and hardware. It is defined as a technology that allows communication and the transmission of information, electronic capture, and processing (Parliamentary Office of Science \& Technology, 2006). We also consider ICT as a means that develops online resources for the effective performance of tasks and simplifies the sharing of electronic data. It is measured as the ultimate function of rural economic development. Findings have revealed that improved output, social and economic development, and more effective government services can all result from progressive ICT use and adoption (Crandall, Lehr, \& Litan, 2007; Gillet, Lehr, \& Sirbu, 2006; LaRose et al., 2008).

In the development of entrepreneurship, ICTs have been utilized as a way of using creativity to reap benefits. Galloway, Mochrie, and Deakins (2004) summarize five case studies of internet forums that employ the potential of ICTs for business activities through the collectivism existing in rural communities in Scotland. The forums were outlined as a gateway that offered local businesses an exclusive selling advantage or brand, constructed in the local setting. The case studies also found that some of the methods by which the forums permitted business expansion, like efficiently repackaging the business, offer ways to discern new markets and a new outlet for accessing customers.

Some developing countries provide opportunities for rural youth entrepreneurs to use ICT for small and micro-enterprise activities. This has been particularly the case in rural areas of Malaysia. According to Hassan et al. (2012), the farming sector in Malaysia is appropriate to more knowledge-intensive businesses, and as this trend intensifies, so too do the prospects for ICT in job creation. Moreover, Mangtsl (2008) identified the mobile telephone as a positive ICT tool in rural development in Malaysia for gaining access to market prices and so on. It is currently the form of ICT that is most accessible to an extensive range of marginalized people in Malaysian rural communities. Moreover, a successful ICT tool in agricultural intervention extends the incentives and competencies of Malaysian young farmers to engage in agri-business by providing information related to updated agricultural issues at any place and time (Hussan et al., 2008). In conclusion, the use of ICT is increasing rapidly with the availability of smartphones, messaging systems, and graphical user interfaces (Hall \& Khan, 2002). This paper demonstrates how the adoption of ICTs can capitalize on some of the special features or behaviour within rural contexts and result in benefits for many rural youth entrepreneurs.

\section{Theoretical Background and Hypothesis Testing}

The technology acceptance model (TAM) has been commonly used by researchers in technology adoption studies that target users' acceptance of a technology (Alshare, Freeze, \& Kwun, 2009; Baker-Eveleth et al., 2006; Davis, Bagozzi, \& Warshaw, 1989; Davis \& Wong, 2007; Goeke \& Faley, 2007; Ha \& Stoel, 2009; Kim \& Bonk, 2006; Lin, 2008; Lin \& Chou, 2009). TAM can provide empirical support to clarify the determinants of behavioral intention in users' adoption of ICT (Agarwal \& Prasad, 1999). The model was developed by Davis in 1981 and it was shown to explain more than $47 \%$ and $51 \%$ of the variance in behavioral intention to use a piece of technology (Davis et al., 1989). A meta-analysis study on TAM from 88 published studies also showed that the model is robust and valid (King \& He, 2006).

Behavioral intention refers to the strength of an individual's intention to employ a specific behavior. For instance, in the context of entrepreneurship, behavioral intention refers to entrepreneurs' intention to start their own business (Engle et al., 2010). TAM comprises the causal relationship between perceived ease of use (PEOU), perceived usefulness (PU), attitude (A), and behavioral intention (BI). According to TAM, PU and PEOU are the main factors in BI, which is explained by AT. In addition, TAM proposes that PU and PEOU are affected by various external variables like user traits and organizational elements. External variables are likely to affect BI by influencing beliefs (PU and PEOU) and AT, and then to affect actual behavior. Acknowledging this and the related literature, this study used the TAM variables; that is, the independent variables are perceived usefulness (PU) and perceived ease of use (PEOU); the dependent variable is enterpreneurial intention (EI); and attitudes (AT) acts as a mediator to explain the impact of the adoption and usage of ICTs by rural youth entrepreneurs and develop the hypotheses. 


\subsection{Perceived Usefulness (PU) and Entrepreneurial Intention (EI)}

Based on TAM, we assume that perceived usefulness (PU) is the degree to which rural youth entrepreneurs believe that adopting ICTs would enhance their enterprise activities in rural communities. Gong, $\mathrm{Xu}$, and $\mathrm{Yu}$ (2004) specified support for people to enhance technology acceptance, asserting that it was necessary to increase the perception of users' usefulness and prepare logical arguments, such as an explanation of the advantage of the new system to the specific user. Several studies have revealed that PU effectively justified the intention to use an IT system (e.g., Davis \& Venkatesh, 2004; Kim, Mannino, \& Nieschwietz, 2009; Loo, Yeow, \& Chong, 2009; Sentosa \& Mat, 2012; Teo \& Noyes, 2011; Wang \& Wang, 2010). For instance, King and He (2006) found that there is a strong relationship between PU and behavioral intention $(\beta=0.51,95 \% \mathrm{CI}=0.46-0.55)$. Based on previous research findings, we tested the following hypothesis:

H1a: There is a positive relationship between perceived usefulness (PU) and entrepreneurial intention (EI).

\subsection{Perceived Usefulness (PU) and Attitudes (AT)}

With regard to TAM, PU influences rural youth entrepreneurs toward using ICT because these entrepreneurs form positive attitudes to ICT, which they believe will positively influence their activities in a rural setting. The findings of previous studies revealed that there is a positive correlation between PU and AT (e.g., Gong et al., 2004; Sánchez-Franco \& Roldan, 2005; Venkatesh \& Bala, 2008). This finding is similar to the results of Hu et al. (1999), who discovered that PU is a significant determinant that inspired physicians' attitudes to using technology in their job performance. Thus, most findings tend to support this association and the following hypothesis was verified:

H1b: There is a positive relationship between perceived usefulness (PU) and attitude (AT).

\subsection{Perceived Ease of Use (PEOU) and Entrepreneurial Intention (EI)}

Perceived ease of use (PEOU) is the second determinant of technology acceptance within TAM (Davis, 1989). In this study, we assume that PU is the degree to which rural youth entrepreneurs believe that using ICT is easier than another system, which is expected to be accepted by other entrepreneurs. A technology acceptance study for TV network web-based news sites was conducted by Lepervanche (2006) and proposed linking use of the website and PEOU. Gefen and Straub (2000) found that PEOU has a positive effect on intention to use technology. Similar findings have been stated by several researchers (Bhattacheijee \& Hikmet, 2008; Cater-Steel \& McBride, 2007; Loo et al., 2009; Sentosa \& Mat, 2012; Teo \& Noyes, 2011), who also concurred with the finding that behavioral intention to use an IT system was influenced by PEOU. With regard to the acceptance of most technologies, it was understood to be true that 'if the platform isn't easy to use and intuitive don't bother with it" (Morgan, 2012, p. 119) and the following hypothesis was verified:

\section{H2a: There is a positive relationship between perceived ease of use (PEOU) and entrepreneurial intention (EI).}

\subsection{Perceived Ease of Use (PEOU) and Attitudes (AT)}

The model suggests systems by which PEOU influences AT (Davis et al., 1989). Some researchers, such as Gong, $\mathrm{Xu}$, and $\mathrm{Yu}$ (2004) and Sanchez-Francis and Roldan (2005), included the attitude construct in their TAM research models. These scholars discovered significant associations between AT and PEOU. As TAM has been applied in online business studies, PEOU has also been realized to be a significant factor in attitude regarding an online store (Moon \& Kim, 2001; O'Cass \& Fenech, 2003). Therefore, based on the findings of these studies the following hypothesis was verified:

H2b: There is a positive relationship between perceived ease of use (PEOU) and attitude (AT).

\subsection{Attitudes (AT) and Entrepreneurial Intention (EI)}

Several studies have shown AT to be one of the factors in ICT acceptance and behavioral intention to use ICT as a result of unwillingness to use ICT (e.g., Shiro, 2008; Zhang \& Aikman, 2007). However, an early study conducted by Igbaria et al. (1997) proposed that AT should be omitted from the model. Some researchers (e.g., Gong et al., 2004; Sánchez-Franco \& Roldan, 2005) have included attitude as a construct within TAM, because a positive attitude is commonly a major part of technology acceptance, which will strengthen users' belief that ICT will help their job performance (Mahmood et al., 2000). In the context of entrepreneurship, many researchers found positive correlations between AT and entrepreneurial intention (EI; Carsrud \& Brännback, 2011; Vardhan, 2012). Based on previous research findings, it is expected that a higher intensity of entrepreneurial attitude will lead to a greater intention to use ICT by rural youth entrepreneurs and the following hypothesis was verified:

H3: There is a positive relationship between attitudes (AT) and entrepreneurial intention (EI) 


\subsection{Attitude (AT) as a Mediator}

With regard to Davis et al. (1989), behavioral intention (BI) is in turn ascertained by attitude (AT) toward technology use. This suggests that ICT adoption by rural youth entrepreneurs could be determined by intention to use, which in turn is held by these entrepreneurs in relation to ICTs. The original terminology of TAM was in keeping with the theory of reasoned action (TRA; Fishbein \& Ajzen, 1975), where beliefs about PU and PEOU were hypothesized to be completely mediated by AT toward using technology. However, based on the empirical analysis of Davis and his colleagues in 1989, a final model of TAM was redefined to omit AT as a result of partial mediation of the impact of beliefs on BI by AT, a fragile direct connection between PU and AT, and a robust direct connection between PEOU and BI (Venkatesh, 2000). In developing our theoretical background, we draw on both the concept of AT potency and earlier technology acceptance studies. Pragmatic analysis of our research hypotheses signifies that:

H4a: Attitude (AT) fully mediates the effects of perceived usefulness (PU) on entrepreneurial intention (EI).

H4b: Attitude (AT) mediates the effects of perceived ease of use (PEOU) on entrepreneurial intention (EI).

\section{Materials and Methods}

A multistage cluster sampling was adopted. Samples of rural youth were selected from four states in peninsular Malaysia; namely, Negeri Sembilan, Selangor, Perlis, and Terengganu. The final sample included 400 rural youth entrepreneurs (256 males and 144 females), resulting in a response rate of about $100 \%$. The sample had an average age of $26.2(\mathrm{SD}=7.3)$, with the majority $(\mathrm{n}=162)$ aged between 20 and 30 years. In terms of educational achievement, $63.5 \%$ of the sample had undergone education at secondary school. Their occupations included students (22.8\%), self-employed (33.1\%), private sector (23.5\%), and government service (11.5\%). $57.4 \%$ of the sample had an income between RM 751 and RM 1,500, with the average verified monthly income RM 1355.42 (1 USD is equivalent to 3.21 Malaysian Ringgit). Finally, 62.6\% of the sample had households of between 4 and 7 members.

The instrument used in this study was self-administered questionnaires, which measured four constructs - PEOU (7), PU (9), AT (7), and EI (8) - through five-point Likert scales, ranging from 1 representing "strongly disagree" to 5 representing "strongly agree." In this study, the items of PU assessed rural youth entrepreneurs" view that using ICT would improve their enterprise activities in the rural setting; the items of PEOU assessed rural youth entrepreneurs' belief that using ICT would be free of effort; the items of AT evaluated rural youth entrepreneurs' evaluation of using ICT in their job; and the items of BI assessed rural youth entrepreneurs' subjective probability of using ICT.

In order to analyze the data, the study used descriptive and inferential statistics. For describing the four constructs, means and standard deviations were employed. The structural equation modeling (SEM) technique, which integrates individual constructs, the measurement model, and the structural model, was used to examine the direct and indirect relationships among constructs within TAM. The sample of 400 for this study met the requirement to use SEM, as a minimum of 200 is an appropriate sample for using the technique (Hoe, 2008).

\section{Results}

The descriptive statistics for the four latent constructs are presented in Table 1. The results show that for the respondents, on average, it is perceived that the ease of using ICT is well above average $(\mathrm{M}=4.128, \mathrm{SD}=.854)$ and the usefulness of ICT in enhancing their enterprise activities even appears to be slightly higher $(M=4.14$, $\mathrm{SD}=.751$ ). It was also found that on average, respondents believed that attitude, their belief about using ICT for accomplishing job tasks, is low on average $(\mathrm{M}=3.75, \mathrm{SD}=.88)$. The results of this study confirmed that rural youth's entrepreneurial intention to use ICT was low, having a mean score of $3.68(\mathrm{SD}=.985)$ on a scale of 1 to 5. A major requirement for SEM is to check for normality by using maximum likelihood estimation techniques (Byrne, 2010). Then, before testing the seven research hypotheses, a normality estimation was analyzed to verify whether normality is met for the data collected or not. With regard to criteria related to normality, data is considered to be normal if skewness is between -2 and +2 (Tabachnick \& Fidell, 2007) and kurtosis is between -7 and +7 (Byrne, 2010). The results of the study showed that skewness ranged from -1.457 to -.397 and kurtosis ranged from -.696 to 1.369 , in which all items were considered to be normal.

In order to test a measurement model for each construct through confirmatory factor analysis (CFA), the convergent and construct validity of each individual construct was examined. In addition, values of Cronbach's alpha $(\alpha)$ in the construct reliabilities were attained for the latent constructs. As shown in Table 1, the Cronbach's alpha values for each scale range from 0.889 to 0.929 , indicating excellent reliability for each individual construct, more than other TAM studies (e.g., Venkatesh \& Davis, 2000). The average variance extracted (AVE) 
values, which ranged from 0.572 to 0.686 , imply that all four constructs have great convergent validities (Hair et al., 2010). For discriminant validity purposes, the result found that the four constructs exhibit sufficient discriminant validity and a potential distinction between the constructs, since AVE for all four constructs was higher than the squared coefficients $\left(\mathrm{r}^{2}\right)$ for each pair (Table 1$)$.

Table 1. Descriptive statistics, construct reliability, AVE estimates, and squared correlation coefficients

\begin{tabular}{lllllllll}
\hline Variables & Mean & SD & $\boldsymbol{\alpha}$ & IU & EI & AT & PU & PEOU \\
\hline EI & 3.68 & .985 & 0.929 & .109 & $(0.686)$ & & & \\
AT & 3.75 & .88 & 0.909 & .221 & 0.54 & $(0.59)$ & & \\
PU & 4.14 & .751 & 0.904 & .0948 & 0.172 & .179 & $(0.575)$ & \\
PEOU & 4.128 & .854 & 0.889 & .072 & .0761 & .097 & 0.358 & $(0.572)$ \\
\hline
\end{tabular}

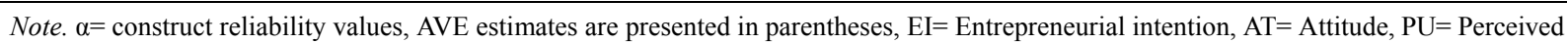
usefulness, PEOU= Perceived ease of use.

The SEM results of the measurement model indicate a good model fit $(\chi 2=932.278, \chi 2 / \mathrm{df}=3.182$, AGFI $=.813$, $\mathrm{GFI}=.844, \mathrm{CFI}=.909, \mathrm{RMSEA}=.074, \mathrm{TLI}=.899, \mathrm{IFI}=.910)$ with two indices (CFI and IFI) that go beyond the cutoff value of 0.90 . The RMSEA value decreases to between 0.03 and 0.08 , which is the proposed range of adequate values (Hair et al., 2010). Since the model has displayed a good fit for the data in this study, the findings of hypothesis testing can now be considered with confidence. In comparison, the mediation model competes with the indirect model, in which all path coefficients from exogenous factors (PU and PEOU) to EI were constrained to zero; also the mediation model competes with the direct model, in which all path coefficients from AT were constrained to zero. As displayed in Table 2, the mediation model takes a better fit to the data in comparison to the indirect and direct models, since the values of TLI, CFI, and IFI all exceed 0.90 and the value of RMSEA is less than 0.08 .

Table 2. Model fit summary and structural model comparisons

\begin{tabular}{lccccccccc}
\hline Model & $\chi^{2}$ & $\chi^{2} / \boldsymbol{d} \boldsymbol{A}$ & AGFI & GFI & CFI & RMSEA & TLI & IFI & AIC \\
\hline MM & 932.278 & 3.182 & .813 & .844 & .909 & .074 & .899 & .910 & 1048.278 \\
IM & 940.149 & 3.187 & .814 & .843 & .908 & .075 & .899 & .909 & 1052.149 \\
DM & 1196.594 & 4.043 & .788 & .821 & .872 & .087 & .860 & .873 & 1306.594 \\
\hline
\end{tabular}

Note. $\mathrm{MM}=$ mediation model, $\mathrm{IM}=$ indirect model, $\mathrm{DM}=$ direct model.

Table 3 presents the path and parameter estimates related to direct, indirect, and mediation models. The findings show that the path coefficients in the direct model indicate that $\mathrm{PU}(\beta=0.39, \mathrm{p}<0.001)$ are significantly related to EI, thus supporting Hypothesis $1 \mathrm{a}$ and satisfying the direct effect condition, while PEOU $(\beta=0.42, p<0.526)$ are not significantly related to EI, thus not supporting Hypothesis $2 \mathrm{a}$. In addition, the path coefficients show that PU $(\beta=0.371, p<0.001)$ are significantly related to AT, while PEOU $(\beta=.09, \mathrm{p}<0.182)$ are not significantly related to AT. These results provide support only for Hypothesis $1 \mathrm{~b}$. Hypothesis 3 is supported, as shown by the significant association between AT and EI $(\beta=0.684, p<0.001)$. In order to address Hypotheses $4 \mathrm{a}$ and $4 \mathrm{~b}$, the causal stage method to test mediation was used. According to Baron and Kenny (1986), mediation happens when (1) the independent variable (IV) is significantly linked to the dependent variable (DV), (2) IV is significantly linked to the mediator, (3) the mediator is significantly linked to DV, and (4) the association between IV and DV decreases on adding the mediator to the model. The findings propose that a partial mediation is established, since the direct effects of PU on EI $(\beta=0.136, p=0.001)$ reduce, but remain significant on the addition of AT acting as the mediator in the model. Hence, Hypothesis 4a was supported. Finally, there is a lack of support for Hypothesis $4 \mathrm{~b}$, since more of the relationships related to PEOU are not significant, which leads to the conclusion that mediation is not possible. 
Table 3. Standardised path coefficients

\begin{tabular}{|c|c|c|c|c|}
\hline $\begin{array}{r}\text { Dependent } \\
\text { Variables } \\
\end{array}$ & $\begin{array}{c}\text { Independent } \\
\text { Variables }\end{array}$ & $\begin{array}{l}\text { Full Mediation } \\
\text { Model }\end{array}$ & $\begin{array}{l}\text { Indirect } \\
\text { Model }\end{array}$ & Direct Model \\
\hline AT & PU. & $.371^{* * *}$ & $.385^{* * *}$ & \\
\hline $\mathrm{AT}$ & PEOU. & .090 & .087 & \\
\hline EI. & $\mathrm{AT}$ & $.684^{* * *}$ & $.740^{* * *}$ & \\
\hline EI. & PU. & $.136^{* *}$ & & $.390^{* * *}$ \\
\hline EI. & PEOU. & -.019 & & .042 \\
\hline
\end{tabular}

PU and PEOU jointly explained $18.5 \%\left(\mathrm{R}^{2}=0.185\right)$ of the variance in AT (Figure 1). Overall, $55.4 \%$ of the variance in EL was accounted for by PU, PEOU, and AT.

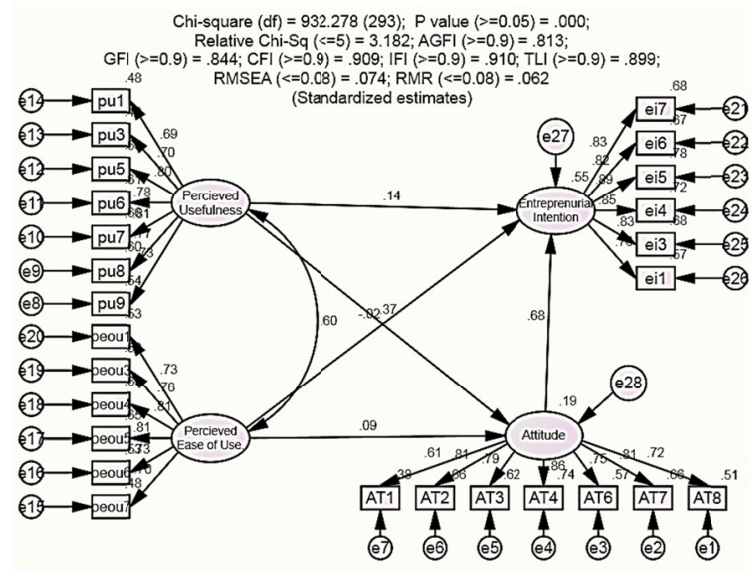

Figure 1. Estimated path coefficients of the mediation model

\section{Discussion and Implications}

According to several TAM studies, the application system was evaluated from the perspectives of perceived usefulness (PU) and perceived ease of use (PEOU; Chiu \& Tsai, 2006; Schaupp, Carter, \& McBride, 2010; Sentosa \& Mat, 2012; Teo \& Noyes, 2011). Thus, rural youth entrepreneurs' motive for using ICTs depends on beliefs in the perceived usefulness (PU) and perceived ease of use (PEOU) of ICTs. Hypotheses 1a and 2a for this research examined how behavioral intention to use ICT is affected by both PEOU and PU of ICT. In this study, only the hypothesis testing results give support to the original TAM that rural entrepreneurs' drive to use ICT is dependent on the PU and not PEOU of ICT use. The result implies that the strength of rural youth entrepreneurs' intention to adopt ICT is shaped by the degree to which they believe that using ICT would improve their job performance. Then, in order to foster the adoption and use of ICT in rural communities, one should seek to implement ICT that users believe would improve their job performance, but not seek to implement ICT that are perceived as easy to use. In addition to the results from testing Hypothesis $1 \mathrm{~b}$, there is enough statistical evidence to suggest that PU of ICT correlates with attitude (A). This result implies that the adoption of ICT by rural youth entrepreneurs in their performance is influenced by their attitude. Therefore, increasing the adoption of ICT among the rural community should inspire rural youth entrepreneurs' attitudes to using those ICT products in performing their job. Furthermore, one significant difference was a partial mediating function of AT between users' beliefs (PU and PEOU) and EI (Davis et al., 1989). The results from the testing of Hypothesis 4a showed that AT partially mediated the PU-EI relationship when it was weak, since the AT-EI relationship would not be robust enough to balance the direct influence of belief in PU on EI. Therefore, belief in PU would influence EI both directly and indirectly through AT toward ICT use when the strength of AT is weak.

The goodness-of-fit results from this study approximate to strengthening the outcome in the original TAM studies as compared with the results of similar previous TAM studies (e.g., Bhattacheijee \& Hikmet, 2008; Cronan \& Al-Rafee, 2008; Loo et al., 2009; Schaupp et al., 2010; Sentosa \& Mat, 2012). In this study, the R ${ }^{2}$ 
values attained narrowly compare with those attained in previous studies, even though we added AT as a mediator within the model (e.g., Davis et al., 1989; Teo \& Noyes, 2011; Venkatesh, 2000; Wang \& Wang, 2010). For instance, in a previous TAM study, PU and PEOU accounted for more than 50\% of the inconsistency in intention to use the system (Teo et al., 2011). Similarly, in this study, PU, PEOU, and AT accounted for almost 54\% of the inconsistency in the entrepreneurial intention to use ICT. Overall, this finding would validate the notion that TAM has the ability to elucidate a relatively large behavioral intent to adopt ICT by youth entrepreneurs in rural communities.

\section{Conclusion}

This study develops and tests the technology acceptance model to capture the factors that may influence rural youth entrepreneurs' decision to use ICT. Nowadays, many governments, including the Malaysian government, have policies that target convincing these entrepreneurs to adopt ICT products as a more efficient method of performing their job. Using the context of ICT acceptance, this study identifies key factors (perceived usefulness) related to youth entrepreneurs' intention to use ICT, specifically in rural communities. The results of this study will not just facilitate an advance in the understanding of the ICT adoption behavior of young entrepreneurs in a rural community, it will also assist policy makers in using the findings to inspire entrepreneurial use of ICT. The current study, however, did not consider any external variables within the original TAM developed by Davis et al. (1989). In future studies, additional research is needed with certain external variables besides youth entrepreneurs in the rural context to confirm the conclusions.

\section{References}

Adam Mahmood, M. O., Burn, J. M., Gemoets, L. A., \& Jacquez, C. (2000). Variables affecting information technology end-user satisfaction: a meta-analysis of the empirical literature. International Journal of Human-Computer Studies, 52(4), 751-771. http://dx.doi.org/10.1006/ijhc.1999.0353

Agarwal, R., \& Prasad, J. (1999). Are individual differences germane to the acceptance of new information technologies? Decision Sciences, 30(2), 361-391. http://dx.doi.org/10.1111/j.1540-5915.1999.tb01614.x

Ahmad, A. R. W., Fauziah Wan, Y., Noor, H. M., \& Ramin, A. K. (2011). Preliminary Study of Rural Entrepreneurship Development Program in Malaysia. Journal of Global Entrepreneurship, 2(1), 537-546.

Alshare, K. A., \& Alkhateeb, F. B. (2008). Predicting students usage of internet in two emerging economies using an extended technology acceptance model (TAM). Academy of Educational Leadership Journal, 12(2), 109-128.

Alshare, K. A., Freeze, R., \& Kwun, O. (2009). Student Intention to Use Expert Systems: AN Exploratory Study. Journal of Computer Information Systems, 49(4), 105-114.

Anandarajan, M., Zaman, M., Dai, Q., \& Arinze, B. (2010). Generation Y adoption of instant messaging: An examination of the impact of social usefulness and media richness on use richness. Professional Communication, IEEE Transactions on, 53(2), 132-143. http://dx.doi.org/10.1109/TPC.2010.2046082

Anderson, D., Tyler, P., \& McCallion, T. (2005). Developing the rural dimension of business-support policy. Environment and Planning C: Government \& Policy, 23(4), 519-536. http://dx.doi.org/10.1068/c44m

Arunachalam, S. (2004). Open Access and the Developing World. The National Medical Journal of India, 17(6), 289-291. Retrieved from http://openmed.nic.in/246/01/Arun-nmji.pdf

Baker-Eveleth, L., Eveleth, D. M., O Neill, M., \& Stone, R. W. (2006). Enabling laptop exams using secure software: Applying the technology acceptance model. Journal of Information Systems Education, 17(4), 413-420.

Baron, R. M., \& Kenny, D. A. (1986). The moderator-mediator variable distinction in social psychological research: Conceptual, strategic, and statistical considerations. Journal of Personality and Social Psychology, 51(6), 1173-1182. http://dx.doi.org/10.1037/0022-3514.51.6.1173

Barrios, S., \& Barrios, D. (2008). Reconsidering Economic Development: The Prospects for Economic Gardening. Public Administration Quarterly, 28(1), 70-101.

Bhattacheijee, A., \& Hikmet, N. (2008). Reconceptualizing organizational support and its effect on information technology usage: evidence from the health care sector. The Journal of Computer Information Systems, 48(4), 69-75.

Byrne, B. M. (2010). Structural equation modeling with AMOS; basic concepts, applications, and programming (2nd ed.). New York/London: Taylor \& Francis. 
Carsrud, A., \& Brännback, M. (2011). Entrepreneurial motivations: what do we still need to know? Journal of Small Business Management, 49(1), 9-26. http://dx.doi.org/10.1111/j.1540-627X.2010.00312.x

Cater-Steel, A., \& McBride, N. (2007). IT service management improvementactor network perspective. Presented at the 15th European Conference on Information Systems, St. Gallen, Switzerland: University of St. Gallen.

Chigunta, F. (2001). An Analysis of Institutional Intervention for Promotion Youth Enterprise Development in Sub-Saharan Africa with Reference to South Africa. In Conference on Development and Transformation at the Cross Roads in South Africa: Challenges of the 21st Century Empowering South Africa Youth for the 21 st Century.

Chigunta, F. (2002). Youth Entrepreneurship: Meeting the Key Policy Challenges. England: Oxford University. Retrieved from http://www.bg.entrep.ta

Chiu, S. F., \& Tsai, M. C. (2006). Relationships among burnout, job involvement, and organizational citizenship behavior. The Journal of Psychology, 140(6), 517-530. http://dx.doi.org/10.3200/JRLP.140.6.517-530

Crandall, R., Lehr, W., \& Litan, R. (2007). The effects of broadband deployment on output and employment: A cross-sectional analysis of U.S. data (No. 6). The Brookings Institution.

Cronan, T. P., \& Al-Rafee, S. (2008). Factors that influence the intention to pirate software and media. Journal of Business Ethics, 78(4), 527-545. http://dx.doi.org/10.1007/s10551-007-9366-8

Curtain, R. (2000). Towards a Youth Employment Strategy (Report to the United Nations on Youth Employment).

Dabson, B. (2007). Entrepreneurship as rural economic development policy: A changing paradigm. Lanham, MD: $\quad$ Lexington $\quad$ Books. Retrieved from http://books.google.com.my/books?hl=en\&lr=\&id=FbIC5sAuGKQC\&oi=fnd\&pg=PA21\&dq=Dabson, +20 07\%2Bentrepreneurship+\&ots=1Q1 ia5XLCK\&sig=D6hpLavW0CnQEbrtdI1sL_438zw

Dabson, B., Malkin, J., Mathews, A., Pate, K., \& Stickle, S. (2003). Mapping Rural Entrepreneurship. Battle Creek, MI: W.K. Kellogg Foundation.

Davis, F. D., Bagozzi, R. P., \& Warshaw, P. R. (1989). User acceptance of computer technology: A comparison of two theoretical models. Management Science, 35(8), 982-1003. http://dx.doi.org/10.1287/mnsc.35.8.982

Davis, F. D., \& Venkatesh, V. (2004). Toward preprototype user acceptance testing of new information systems: implications for software project management. Engineering Management, IEEE Transactions on, 51(1), 31-46. http://dx.doi.org/10.1109/TEM.2003.822468

Davis, R., \& Wong, D. (2007). Conceptualizing and measuring the optimal experience of the eLearning environment. Decision Sciences Journal of Innovative Education, 5(1), 97-126. http://dx.doi.org/10.1111/j.1540-4609.2007.00129.x

Engle, R. L., Dimitriadi, N., Schlaegel, C., Delanoe, S., Alvarado, I., He, X., \& Wolff, B. (2010). Entrepreneurial intent: A Twelve-Country Evaluation of Ajzen's Model of Planned Behaviour. International Journal of Entrepreneurial Behaviour \& Research, 16(1), 35-57. http://dx.doi.org/10.1108/13552551011020063

Fishbein, M., \& Ajzen, I. (1975). Belief, attitude, intention and behavior: An introduction to theory and research. Reading, MA: Addison-Wesley. Retrieved from http://trid.trb.org/view.aspx?id=1150648

Galloway, L., Mochrie, R., \& Deakins, D. (2004). ICT-enabled collectivity as a positive rural business strategy. International Journal of Entrepreneurial Behaviour \& Research, 10(4), 247-259. http://dx.doi.org/10.1108/13552550410544213

Gefen, D., \& Straub, D. W. (2000). The relative importance of perceived ease of use in IS adoption: a study of e-commerce adoption. Journal of the Association for Information Systems, 1(1), 1-27.

Ghazy, M. M., Senousy, W. M., Aatty, A. M., \& Kamel, M. (2008). Performance evaluation of a waste stabilization pond in a rural area in Egypt. American Journal of Environmental Sciences, 4(4), 316-325. http://dx.doi.org/10.3844/ajessp.2008.316.325

Gillet, S., Lehr, W., \& Sirbu, M. (2006). Measuring the economic impact of broadband deployment (No. 99-07-13829). Washington, DC: Economic Development Administration, U.S. Department of Commerce.

Goeke, R. J., \& Faley, R. H. (2007). Leveraging the flexibility of your data warehouse. Communications of the ACM, 50(10), 107-111. http://dx.doi.org/10.1145/1290958.1290970 
Gong, M., Xu, Y., \& Yu, Y. (2004). An enhanced technology acceptance model for web-based learning. Journal of Information Systems Education, 15(4), 365-374.

Ha, S., \& Stoel, L. (2009). Consumer e-shopping acceptance: Antecedents in a technology acceptance model. Journal of Business Research, 62(5), 565-571. http://dx.doi.org/10.1016/j.jbusres.2008.06.016

Hair, J. F., Black, W. C., Babin, B. J., Anderson, R. E., \& Tatham, R. L. (2010). Multivariate data analysis (7th ed.). Englewood Cliffs (NJ): Prentice Hall. Retrieved from http://dx.doi.org/10.1016/j.jmva.2009.12.014

Hall, B., \& Khan, B. (2002). Adoption of new technology. New Economy handbook. Retrieved from http://elsa.berkeley.edu/ bhhall/papers/HallKhan03\%20diffusion.pdf

Henderson, J., Low, S., \& Weiler, S. (2007). The Drivers of Regional Entrepreneurship in Rural and Metro Areas. In N. Walzer (Ed.), Entrepreneurship and Local Economic Development (pp. 81-102). Lanham, MD: Lexington Books.

Henderson, J. R. (2002). Will the rural economy rebound with the rest of the nation? Center for the Study of Rural America. Federal Reserve Bank of Kansas City.

Hoe, S. L. (2008). Issues and procedures in adopting structural equation modeling technique. Journal of Applied Quantitative Methods, 3(1), 76-83.

Hollifield, C., \& Donnermeyer, J. (2003). Creating demand: Influencing information technology diffusion in rural communities. Government Information Quarterly, 20(2), 135-150. http://dx.doi.org/10.1016/S0740-624X(03)00035-2

Hu, P. J., Chau, P. Y., Sheng, O. R. L., \& Tam, K. Y. (1999). Examining the technology acceptance model using physician acceptance of telemedicine technology. Journal of Management Information Systems, 16(2), 91-112.

Hussan, M. S., Musa, A. H., Bahaman, A. S., Ismail, N., \& Shaffri, H. A. M. (2008). Agricultural based entrepreneurs usage of ICT-problems and prospect. In S. Nagatsukaan (Ed.), AALD (pp. 753-762). Tokyo, Japan.

Igbaria, M., Zinatelli, N., Cragg, P., \& Cavaye, A. L. M. (1997). Personal computing acceptance factors in small firms: a structural equation model. MIS Quarterly, 21(3), 279-305. http://dx.doi.org/10.2307/249498

ILO. (2008). Global Employment Trends for Youth. Retrieved from http:/www.ilo.org/wcmsp5/groups/public/dgreports/dcomm/documents/publication/wcms_077664.pdf

Kim, H. J., Mannino, M., \& Nieschwietz, R. J. (2009). Information technology acceptance in the internal audit profession: Impact of technology features and complexity. International Journal of Accounting Information Systems, 10(4), 214-228. http://dx.doi.org/10.1016/j.accinf.2009.09.001

Kim, K., \& Bonk, C. J. (2006). The future of online teaching and learning in higher education: The survey says. Educause Quarterly, 29(4), 22-30.

King, W. R., \& He, J. (2006). A meta-analysis of the technology acceptance model. Information \& Management, 43(6), 740-755. http://dx.doi.org/10.1016/j.im.2006.05.003

LaRose, R., Gregg, J., Strover, S., Straubhaar, J., \& Inagaki, N. (2008). Closing the rural broadband gap (CREES Program No. 2004-35401-14985). Washington, DC: U.S. Department of Agriculture.

Lepervanche, J. G. (2006). User technology acceptance of TV network news web sites: A survey analysis (PhD dissertation). Retrieved from ProQuest Dissertation and Thesis database. (UMI No. 304909005).

Lichtenstein, G., Lyons, T., \& Kutzhanova, N. (2004). Building Entrepreneurial Communities: The Appropriate Role of Enterprise Development Activities. Journal of the Community Development Society, 35(1), 5-24. http://dx.doi.org/10.1080/15575330409490119

Lin, H. F. (2008). Predicting consumer intentions to shop online: An empirical test of competing theories. Electronic Commerce Research and Applications, 6(4), 433-442. http://dx.doi.org/10.1016/j.elerap.2007.02.002

Lin, P. C., \& Chou, Y. H. (2009). Perceived usefulness, ease of use, and usage of citation database interfaces: a replication. Electronic Library, 27(1), 31-42. http://dx.doi.org/10.1108/02640470910934579

Liu, X. (2010). Empirical testing of a theoretical extension of the technology acceptance model: An exploratory study of educational wikis. Communication Education, 59(1), 52-69. http://dx.doi.org/10.1080/03634520903431745 
Llisterri, J., Kantis, H., Angelelli, P., \& Tejerina, L. (2006). Is youth entrepreneurship a necessity or an opportunity? A first exploration of household and new enterprise surveys in Latin America. Washington, DC: IDB.

Loo, W. H., Yeow, P. H. P., \& Chong, S. C. (2009). User acceptance of Malaysian government multipurpose smartcard applications. Government Information Quarterly, 26(2), 358-367. http://dx.doi.org/10.1016/j.giq.2008.07.004

Mangtsl, A. (2008). Emerging issue, priorities and commitments in agriculture. Agricultural Information Worldwide, 1(3), 5-6.

Markley, D., Macke, D., \& Luther, V. (2005). Energizing Entrepreneurs: Charting a Course for Rural Communities. Heartland Center for Leadership Development.

McMullen, J. S., Bagby, D. R., \& Palich, L. E. (2008). Economic freedom and the motivation to engage in entrepreneurial action. Entrepreneurship Theory and Practice, 32, 875-895. http://dx.doi.org/10.1111/j.1540-6520.2008.00260.x

Moon, J. W., \& Kim, Y. G. (2001). Extending the TAM for a World-Wide-Web context. Information \& Management, 38(4), 217-230. http://dx.doi.org/10.1016/S0378-7206(00)00061-6

Morgan, L. (2012). Generation Y, learner autonomy and the potential of Web 2.0 tools for language learning and teaching. Campus-Wide Information Systems, 29(3), 166-176. http://dx.doi.org/10.1108/10650741211243184

Mutezo, A. T. (2005). Obstacles in the Access to SMME Finance: An Empirical Perspective on Tswane. Retrieved from http: //www.etd.unisa.ac.za/ETD-db

Norhaiyati, A. M., Nik, M. N., \& Md, W. Z. W. M. (2011). The influential factors in decision-making process among Malay Women Entrepreneurs. Kuala Lumpur, Malaysia: The Institute for the Empowerment of Women.

O'cass, A., \& Fenech, T. (2003). Web retailing adoption: exploring the nature of internet users web retailing behaviour. Journal of Retailing and Consumer Services, 10(2), 81-94. http://dx.doi.org/10.1016/S0969-6989(02)00004-8

Omolo, I. O. (2011). Do New Technology-Based Firms Located in Science Parks Really Perform. Universitas Osloensis. Retrieved from https://www.duo.uio.no/handle/10852/12903

Pages, E., Freedman, D., \& Von Bargen, P. (2003). Entrepreneurship as a State and Local Economic Development Strategy. In D. Hart (Ed.), The Emergence of Entrepreneurship Policy (2nd ed., pp. 240-259). Thousand Oaks, CA: Sage. Retrieved from http://dx.doi.org/10.1017/CBO9780511610134.013

Parliamentary Office of Science \& Technology. (2006).

Plessis, V. (2004). Self-employment activity in rural Canada (No. 21). Statistics Canada, Catalogue. Retrieved from http://dsp-psd.tpsgc.gc.ca/Collection/Statcan/21-006-X/21-006-XIE2004005.pdf

Rahman, M. A., Mahfuz, M. U., Ahmed, K. M., \& Rajatheva, R. (2005). ICT based sustainable rural business opportunities in developing countries: A wireless-networked RCP-RAP approach. American Journal of Applied Sciences, 2(8), 1256-1260. http://dx.doi.org/10.3844/ajassp.2005.1256.1260

Ramsey, E., Ibbotson, P., Bell, J., \& Gray, B. (2003). E-opportunities of service sector SMEs: an Irish cross-border study. Journal of Small Business and Enterprise Development, 10(3), 250-264. http://dx.doi.org/10.1108/14626000310489709

Sabri, B., Yahaya, N., Muhazzab, S., Mohd Salleh, N., Abu Talib, M., Abd Halim, A., .. Mahenthran, H. (2008). Aspirasi Keusahawanan belia terhadap Memupuk Budaya Keusahawanan ke arah menuju Pencapaian Wawasan 2020. Buletin Institut Penyelidikan Pembangunan Belia Malaysia, 1.

Sánchez-Franco, M. J., \& Roldan, J. L. (2005). Web acceptance and usage model: A comparison between goal-directed and experiential web users. Internet Research, 15(1), 21-48. http://dx.doi.org/10.1108/10662240510577059

Schaupp, L. C., Carter, L., \& McBride, M. E. (2010). E-file adoption: A study of US taxpayers' intentions. Computers in Human Behavior, 26(4), 636-644. http://dx.doi.org/10.1016/j.chb.2009.12.017

Schoof, U. (2006). Stimulating Youth Entrepreneurship: Barriers and incentives to enterprise start-ups by young people (Working Paper No. 76). Geneva, Switzerland: ILO. 
Sentosa, I., \& Mat, N. K. (2012). Examining a theory of planned behavior (TPB) and Technology acceptance model (TAM) in Internet purchasing using structural equation Modeling. Journal of Arts, Science \& Commerce, 3(2), 62-77.

Shiro, U. (2008). A case study of DIY ICT. Information, 10(4), 46-60.

Tabachnick, B. G., \& Fidell, L. S. (2007). Experimental designs using ANOVA (5th ed.). NY: Allyn and Bacon.

Teo, T., \& Noyes, J. (2011). An assessment of the influence of perceived enjoyment and attitude on the intention to use technology among pre-service teachers: A structural equation modeling approach. Computers \& Education, 57(2), 1645-1653. http://dx.doi.org/10.1016/j.compedu.2011.03.002

Vardhan, J. (2012). A binary logistic regression model for entrepreneurial motivation among university students-A UAE perspective. Journal of Educational and Social Research, 2(3), 75-86.

Venkatesh, V. (2000). Determinants of perceived ease of use: Integrating control, intrinsic motivation, and emotion into the technology acceptance model. Information Systems Research, 11(4), 342-365. http://dx.doi.org/10.1287/isre.11.4.342.11872

Venkatesh, V., \& Bala, H. (2008). Technology Acceptance Model 3 and a Research Agenda on Interventions. Journal of Information Technology, 39(2), 273-315.

Venkatesh, V., \& Davis, F. (2000). A theoretical extension of the Technology Acceptance Model: four longitudinal field studies. Management Science, 46(2), 186-204.

Wang, H. Y., \& Wang, S. H. (2010). User acceptance of mobile internet based on the unified theory of acceptance and use of technology: Investigating the determinants and gender differences. Social Behavior and Personality: An International Journal, 38(3), 415-426. http://dx.doi.org/10.2224/sbp.2010.38.3.415

White, S., \& Kenyon, P. (2000). Enterprise-based Youth Employment Policies, Strategies and Programs. Geneva: ILO.

Wolcott, P., Mehruz, K., \& Sajda, Q. (2008). Meeting the challenges of ICT adoption by micro-enterprises. Journal of Enterprise Information Management, 21(6), 616-632. http://dx.doi.org/10.1108/17410390810911212

Wortman, M. S. (1990). Rural Entrepreneurship Research: An Integration Into the Entrepreneurship Field. Agribusiness, 6(4), 329-344. http://dx.doi.org/10.1002/1520-6297(199007)6:4<329::AID-AGR2720060405>3.0.CO;2-N

Yuen, A. H., \& Ma, W. W. (2008). Exploring teacher acceptance of e-learning technology. Asia-Pacific Journal of Teacher Education, 36(3), 229-243. http://dx.doi.org/10.1080/13598660802232779

Zhang, P., \& Aikman, S. (2007). Attitudes in ICT acceptance and use. In J. Jacko (Ed.), Human-Computer Interaction (pp. 1021-1030). Syracuse, NY: Springer. Retrieved from http://link.springer.com/chapter/10.1007/978-3-540-73105-4_112

\section{Copyrights}

Copyright for this article is retained by the author(s), with first publication rights granted to the journal.

This is an open-access article distributed under the terms and conditions of the Creative Commons Attribution license (http://creativecommons.org/licenses/by/3.0/). 